\title{
Pemberdayaan Peserta Didik Melalui Program Kewirausahaan, Pendidikan Lingkungan, dan Budaya Literasi
}

\author{
Barotun Mabaroh $^{1}$, Achmad Nadif $^{2}$, Sugianti $^{3}$, Miftahul Khoiri ${ }^{4}$, Evi Sulistyowati ${ }^{5}$ \\ ${ }^{1,2,3,4}$ Universitas PGRI Wiranegara \\ ${ }^{5} \mathrm{MA}$ Al Furqon Pasuruan \\ email : barotunmabaroh@gmail.com¹, nadif18@gmail.com²,wewangiceria@yahoo.co.id², \\ sulistyowati.evu@gmail.com ${ }^{5}$
}

\begin{abstract}
The community service through Thematic Field Work (KKNT) aims to build an entrepreneurial spirit, process waste into useful items, and create a culture of literacy for students in the MA Al Furqon Bugul Lor school, Pasuruan City. Activities in the form of delivering socialization and training in making praline chocolates. In also, the KKNT service team also provided training in making handicrafts from rags to key chains, crossbars, and pencil cases. Environmental education activities in the form of socialization to students regarding making organic and non-organic trash bins and planting ornamental plants in used bottles. With this activity, it is hoped that students will realize how important it is to care for the environment. The final activity is to improve the literacy culture for students by making motivation boards, labeling, and rearranging the school library into a more representative reading room. The results of the KKNT activities received satisfactory responses and appreciation from the school. The KKNT service team hopes this activity can be carried out on an ongoing basis to encourage the creativity of students.
\end{abstract}

Keywords: entrepreneurial, environmental education, literacy culture

\begin{abstract}
Abstrak
Program pengabdian kepada masyarakat melalui Kuliah Kerja Nyata Tematik (KKNT) bertujuan membangun jiwa kewirausahaan, mengolah sampah menjadi barang berguna, dan menciptakan budaya literasi bagi siswa-siswi di lingkungan sekolah MA Al Furqon Bugul Lor Kota Pasuruan. Kegiatan berupa penyampaian sosialisasi dan pelatihan pembuatan coklat praline. Selain itu, tim pengabdian KKNT juga memberikan pelatihan pembuatan kerajinan tangan dari kain perca menjadi gantungan kunci, bross, dan kotak pensil. Kegiatan pendidikan lingkungan berupa sosialisasi kepada siswa-siswi mengenai pembuatan tempat sampah organik dan nonorganik serta penanaman tanaman hias pada botol bekas. Dengan kegiatan ini diharapkan siswa-siswi menyadari betapa pentingnya kepedulian terhadap lingkungan. Kegiatan terakhir adalah meningkatkan budaya literasi bagi siswa-siswi melalui pembuatan papan motivasi, labelling, dan penataan ulang perpustakaan sekolah menjadi ruang baca yang lebih representatif. Hasil dari kegiatan KKNT mendapatkan respon dan apresiasi yang memuaskan dari pihak sekolah. Tim pengabdian KKNT berharap kegiatan ini dapat dilaksanakan secara berkesinambungan untuk mendorong kreatifitas siswa-siswi.
\end{abstract}

Kata Kunci: kewirausahaan, pendidikan lingkungan, budaya literasi

Artikel diterima : 21 Januari $2021 \quad$ direvisi : 9 Februari $2021 \quad$ disetujui : 19 Februari 2021 


\section{Pendahuluan}

Setiap orang pasti memiliki jiwa kewirausahaan dan kreativitas dalam diri mereka (Suharyono, 2018). Namun jiwa kewirausahaan dan kreativitas ini harus dan perlu diarahkan serta dikembangkan, karena setiap individu memiliki jiwa kewirausahaan dan kreativitas yang berbedabeda. Menurut Hisrich et al. (2008) kewirausahaan adalah proses penciptaan sesuatu yang baru pada nilai dengan menggunakan waktu dan upaya yang diperlukan, menanggung risiko keuangan, fisik, serta risiko sosial yang mengiringi, menerima imbalan moneter yang dihasilkan serta kepuasan dan kebebasan pribadi.

Pengertian kreativitas menurut Hadiyati (2011) adalah inisiatif terhadap suatu produk atau proses yang bermanfaat, benar, tepat, dan bernilai terhadap suatu tugas yang lebih bersifat heuristik yaitu sesuatu yang merupakan pedoman, petunjuk, atau panduan yang tidak lengkap yang akan menuntun kita untuk mengerti, mempelajari, atau menemukan sesuatu yang baru. Berdasarkan definisi kewirausahaan dan kreativitas menurut beberapa ahli di atas, dapat dikatakan jika setiap orang dapat menciptakan sesuatu atau ide yang dapat menghasilkan hal yang berharga dan bernilai, dengan rasa tanggung jawab dan tidak mudah menyerah.

Pengajaran kewirausahaan dapat dikembangkan kepada siswa selama mereka berada dibangku sekolah. Semakin awal kewirausahaan diajarkan maka semakin baik jiwa kewirausahaan mereka kelak. Begitu juga dengan kreativitas, di lingkungan sekolah siswa dapat menjadikan mereka lebih kreativitas dan inovatif. Menurut Alex (2012) bahwa sampah adalah barang yang tidak berharga, tidak memiliki nilai ekonomis, tidak berguna dan barang yang sudah tidak diinginkan lagi. Sampah plastik adalah salah satu barang yang dapat dijadikan sebagai bahan kreativitas bagi siswa. Apabila siswa dapat mendaur ulang barang bekas atau sampah yang sulit terurai menjadi suatu barang yang bermanfaat dan mempunyai nilai jual.

Program pengabdian Kuliah Kerja Nyata Tematik (KKNT) adalah bentuk kegiatan pengabdian kepada masyarakat yang dilakukan oleh mahasiswa dengan pendekatan lintas keilmuan dan sektoral pada waktu dan di daerah tertentu yang berfokus pada daerah sekolah di Pasuruan. Karena berbasis pendidikan, maka untuk pelaksanaan program KKN Tematik diadakan di sekolah-sekolah, khususnya tingkat SMA/SMK/MA sederajat.

Kegiatan KKN Tematik dilaksanakan di MA Al Furqon Pasuruan. MA Al Furqon merupakan salah satu Madrasah Aliyah Swasta yang bertempat di Jl. Imam Bonjol No. 99 Bugul Lor Panggungrejo Kota Pasuruan. Berdasarkan hasil pengamatan tim pengabdian KKNT di lapangan serta penyampaian pertanyaan kepada pihak sekolah. Tim pengabdian KKNT memilih MA Al Furqon Pasuruan dengan alasan yaitu kurangnya pelatihan di bidang kewirausahaan, masih kurangnya sosialisasi mengenai penataan lingkungan sekolah, dan minimnya budaya literasi di kalangan siswa. Oleh karena itu, tim membuat 3 (tiga) tema KKNT yaitu pertama Pendidikan Kewirausahaan, kedua Pendidikan Lingkungan, dan yang ketiga Pembudayaan Berliterasi.

Program pertama yang dilaksanakan adalah Pendidikan Kewirausahaan. Kewirausahaan adalah suatu ilmu yang mengkaji tentang pengembangan dan pembangunan semangat kreativitas serta berani menanggung resiko terhadap pekerjaan yang dilakukan demi mewujudkan hasil karya tersebut (Fahmi, 2013). Dengan kata lain kewirausahaan adalah kemampuan untuk menciptakan sesuatu yang baru dan berbeda dari yang lain. Pendidikan Kewirausahaan yang dilaksanakan pertama adalah pelatihan pembuatan coklat praline. Coklat praline adalah permen karakter yang terbuat dari coklat yang berisi kacang-kacangan atau selai. Pendidikan Kewirausahaan yang kedua adalah pembuatan kerajinan tangan dari kain perca, 
yang hasilnya menjadi barang yang berguna dan mempunya nilai ekonomi seperti gantung kunci, bross, dan kotak pensil.

Program kedua adalah Pendidikan Lingkungan yang diajarkan kepada siwasiswi MA Al Furqon. Diharapkan nantinya siswa mempunyai sikap peduli lingkungan. Menurut Muhammad (2013) bahwa peduli lingkungan adalah sikap dan tindakan yang berupaya mencegah kerusakan alam di lingkungan alam di sekitarnya, dan mengembangkan upaya-upaya untuk memperbaiki kerusakan alam yang sudah terjadi. Kegiatan bertema pendidikan lingkungan yang dilakukan adalah pemanfaatan botol plastik yang tidak terpakai menjadi taman yang cantik, memanfaatkan tempat bekas cat menjadi tempat sampah yang berguna yang disebut tempat sampah organik dan non organik.

Program ketiga adalah Budaya Literasi. Literasi menurut Kemendikbud (2016) adalah kemampuan mengakses, memahami, dan menggunakan sesuatu secara cerdas melalui berbagai aktivitas, antara lain membaca, melihat, menyimak, menulis, dan berbicara. Kegiatan KKNT bertema literasi yang dilakukan adalah membenahi label ruangan yang tidak sesuai dan membuat papan motivasi ditempatkan di lingkungan sekolah yang bertujuan agar siswa termotivasi dan menerapkan budaya literasi di lingkungan sekolah.

Kegiatan KKNT bertujuan untuk (1)Menumbuhkan jiwa kewirausahaan. Tim pengabdian memberikan pelatihan kewirausahaan berupa pembuatan coklat praline dan karakter yang kekinian dan pembuatan kerajinan tangan yang mempunyai nilai jual di masyarakat; (2)Membuat penataan lingkungan sekolah lebih bagus. Tim pengabdian memberikan sosialisasi mengenai penataan lingkungan, pelatihan penanaman tanaman dengan pot dari barang bekas, dan pembuatan tempat sampah organik dan non organik; (3)Menciptakan budaya literasi bagi siswa di lingkungan sekolah. Tim pengabdian meningkatkan budaya literasi dengan memberikan sosialisasi mengenai literasi tulis disertai dengan pembuatan labelling ruangan, dan pembuatan papan motivasi.

\section{Metode dan Pelaksanaan}

Kegiatan yang dilakukan terlebih dahulu melakukan observasi di MA Al Furqon Bugul Lor. Kegiatan observasi bertujuan melihat situasi dan kondisi di lingkungan sekolah dan melakukan koordinasi dengan pihak sekolah.. Kemudian dari hasil observasi tersebut dibuat tema Pendidikan Kewirausahaan, Pendidikan Lingkungan dan Budaya Literasi. Tahap pelaksanaan kegiatan KKNT di sekolah terdiri dari :

\section{Tahap Penyusunan dan Penjadwalan Program Kerja}

Tahap awal yang dilakukan adalah persiapan program kerja dan penjadwalan hari pelaksanaan. Serta pembentukan tim pengabdian KKNT untuk mempersiapkan sarana dan prasarana sesuai dengan tugas masing-masing dalam tema kewirausahaan, lingkungan dan literasi. Setiap tema mempunyai dua program yang dilaksanakan yaitu: (1) Tema kewirausahaan ialah prorgram pelatihan pembuatan coklat praline dan pelatihan kerajinan tangan dari kain perca; (2) Tema lingkungan ialah program pembuatan tempat sampah dari tempat bekas cat dan daur ulang botol plastik menjadi pot bunga; dan (3) Tema literasi pembuatan papan motivasi dan labeling ruangan.

\section{Tahap Sosialisasi kepada siswa siswi MA Al Furqon}

Tahap ini tim pengabdian KKNT melakukan sosialisasi terlebih dahulu kepada siswa-siswi MA Al Furqon Bugul Lor. Sosialisasi ini bertujuan untuk memberikan pemahaman awal tetang kegiatan apa saja yang akan dilakukan. Sosialisasi ini melibatkan siswa kelas X, XI, dan XII.

\section{Tahap Pelaksanaan}

Tahap ini tim pengabdian mengajak siswa siswi untuk mempraktekkan apa yang telah disampaiakan pada kegiatan sosialisasi sebelumnya. Kegiatan praktek 
ini juga memberikan kebebasan bagi vitas mereka tersalurkan dengan baik. siswa-siswi untuk berkreasi. Agar kreati-

Tabel 1.

Program Kerja KKN-Tematik

\begin{tabular}{|c|c|c|c|}
\hline No. & Kegiatan & Tanggal Pelaksanaan & $\begin{array}{l}\text { Penanggung } \\
\text { Jawab }\end{array}$ \\
\hline 1 & $\begin{array}{l}\text { Sosialisasi dan Pelatihan Pembuatan } \\
\text { Coklat Praline dan Karakter }\end{array}$ & 15-16 November 2019 & $\begin{array}{l}\text { Reni Nur } \\
\text { Setiawati }\end{array}$ \\
\hline 2 & $\begin{array}{l}\text { Sosialisasi dan Pelatihan Pembuatan } \\
\text { Kerajinan Tangan }\end{array}$ & 18-20 November 2019 & $\begin{array}{l}\text { Nanda Ayu } \\
\text { Ramadani }\end{array}$ \\
\hline 3 & $\begin{array}{l}\text { Sosialisasi dan Pembuatan Tempat } \\
\text { Sampah Organik dan Non Organik }\end{array}$ & $\begin{array}{l}21 \& 23 \text { November } \\
2019\end{array}$ & Laili Alfiatul Izza \\
\hline 4 & $\begin{array}{l}\text { Sosialisasi dan Pelatihan Penanaman } \\
\text { Tanaman dalam Pot Bekas }\end{array}$ & 25-27November 2019 & $\begin{array}{l}\text { Aini Maftukhatul } \\
\text { L. }\end{array}$ \\
\hline 5 & $\begin{array}{l}\text { Sosialisasi dan Pembuatan Papan } \\
\text { Motivasi }\end{array}$ & 28-29 November 2019 & Dewi Zuhriyah \\
\hline 6 & Labelling Ruangan & 30 November 2019 & Rohmania \\
\hline
\end{tabular}

Sumber : Penulis, 2021.

\section{Hasil dan Pembahasan}

Pengabdian kepada masyarakat melalui kegiatan KKNT dilaksanakan pada tanggal 12 November 2019 sampai dengan tanggal 14 Desember 2019 di MA Al Furqon Bugul Lor. Tema dan bentuk kegiatan yang dilaksanakan dalam KKNT Berbasis Pendidikan berfokus pada 1) Pendidikan Lingkungan; 2) Pendidikan Kewirausahaan; dan 3) Pembudayaan berliterasi di lingkungan sekolah.

Kegiatan ini bertujuan sebagai salah satu upaya untuk membantu pelaksanaan program peningkatan pelestarian lingkungan sekolah menuju sekolah yang ramah lingkungan melalui pendidikan lingkungan, meningkatkan pengetahuan dan keterampilan masyarakat untuk mandiri secara ekonomi melalui pendidikan kewirausahaan, dan meningkatkan pengetahuan dan keterampilan dalam berliterasi untuk meningkatkan kualitas kehidupan. Pelaksanaan kegiatan pengabdian KKNT dilaksanakan sesuai jadwal yang dibuat agar kegiatan terlaksana tepat waktu.

\section{Kegiatan pertama (15-16 November 2019)}

Sosialisasi dilaksanakan pada hari Jumat tanggal 15 November 2019 Pukul 10.00-11.00 WIB. Sosialisasi dilaksanakan di sebuah ruangan sekolah. Sasaran tim pengabdian yaitu semua peserta didik mulai dari kelas X, XI, dan XII. Tim pengabdian berupaya untuk menanamkan jiwa kewirausahaan dan bisa menuangkan kreasi mereka di bidang kewirausahaan. Setelah acara sosialisasi, tim pengabdian melaksanakan pelatihan. Pelatihan dilaksanakan hari Sabtu tanggal 16 November 2019. Pelatihan tersebut dilakukan secara berkelompok, 1 (satu) kelompok beranggotakan 5 (lima) siswa. Setiap kelompok mempraktekkan sendiri pembuatan coklat praline dengan kreatifitas dan semenarik mungkin.

Sebelum hari pelaksanaan, tim pengabdian KKNT telah mempersiapkn bahan-bahan yang dibutuhkan untuk membuat coklat praline yang siap jual. Selain itu, tim pengabdian juga mengupayakan alat masak untuk membuat coklat praline, yaitu: kompor, panci, spatula, cetakan berbentuk love, hello kitty, mawar, boneka dan lain sebagainya. Untuk kemasan, tim pengabdian menyediakan 
stick coklat, plastik, dan pita produk hasil pelatihan lebih menarik.

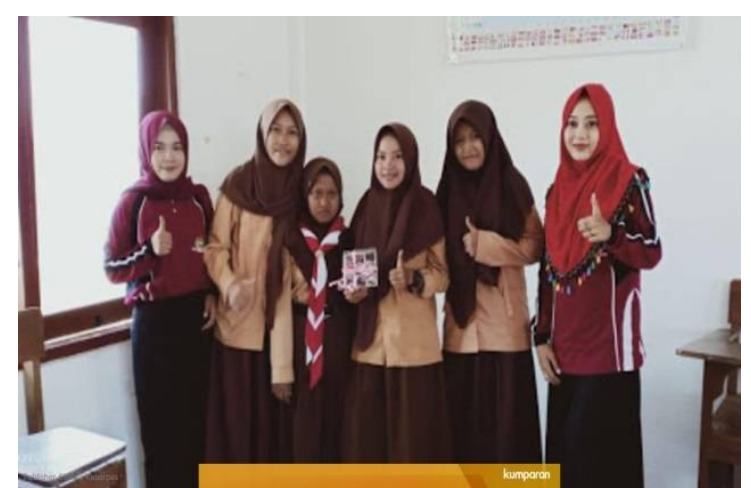

Gambar 1.Tim pengabdian KKNT dan siswi MA Al Furqon menghasilkan coklat praline

Setelah diadakan sosialisasi Dan pelatihan pembuatan coklat praline. Hasil dari siswa siswi dari kelompok satu dengan yang lain berbeda, karena cetakan coklat yang diberikan sangat bervariasi seperti cetakan love, cetakan hello kitty, cetakan permen mawar, cetakan boneka dan masih banyak yang lainnya. Siswa dibebaskan untuk membuat coklat praline sesuai keinginan mereka. Setelah coklat praline jadi terdapat perbedaan hasil pembuatan coklat praline bergantung tingkat ketlatenan dari siswa sendiri. Jika siswa sangat telaten maka hasilnya akan bagus dan jika siswa kurang telaten maka hasilnya kurang maksimal. Dan siswa sangat senang karena hasil pembuatan coklat praline memuaskan dan hasilnya diberikan kepada guru dan kepala sekolah.

\section{Kegiatan kedua (18-20 November 2019)}

Kegiatan kedua seperti kegiatan pertama yaitu terlebih dahulu diadakan sosialisasi pada tanggal 18 November 2019, kemudian keesokan harinya pada tanggal 19-20 November 2019 siswa melaksanakan praktek mengolah kerajinan tangan dari limbah kain perca menjadi aneka aksesoris. Siswa dibagi berkelompok dan masing-masing kelompok harus menghasilkan masing-masing satu produk dari tiap aksesoris yang sudah ditentukan.
Meskipun tidak semua siswa hadir, akan tetapi tidak mengurangi rasa semangat untuk membuat kerajinan. Banyak siswa terlihat antusias untuk menjahit meskipun itu pertama kalinya kegiatan dilakukan. Siswa membuat aneka aksesoris dengan kreatifitas masing-masing. Setelah semua siswa membuat aneka aksesoris, dilanjutkan dengan proses pengemasan diberi pembungkus plastik agar mempunyai nilai jual. Seluruh kegiatan dibuatkan dokumentasi seperti gambar $2 \mathrm{di}$ bawah ini.

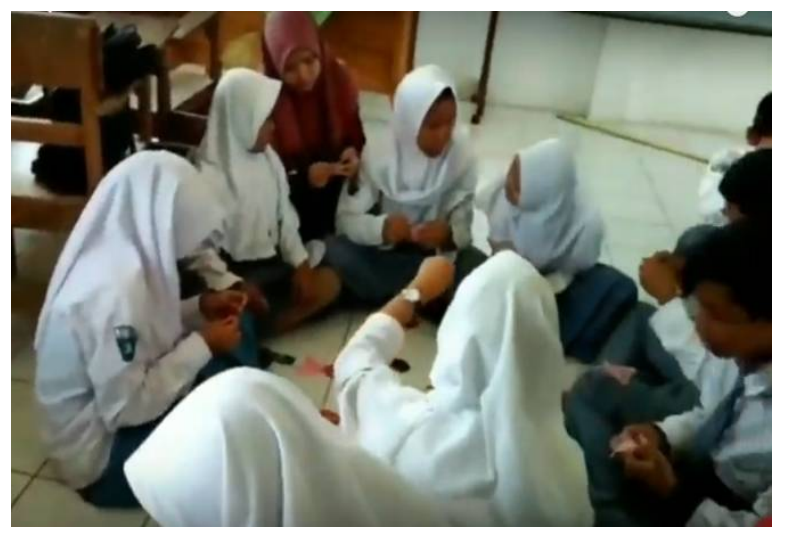

Gambar 2. Pembuatan Kerajinan dari Kain Perca

\section{Kegiatan ketiga (21 \& 23 November 2019)}

Kegiatan berikutnya yaitu sosialisasi dan pembuatan tempat sampah organik dan nonorganik. Tanggal 21 November 2019 adalah kegiatan sosialisasi. Hasil dari sosialisasi adalah tumbuhnya rasa peduli peserta didik di MA Al Furqon Pasuruan terhadap lingkungan untuk tidak membuang sampah pada tempatnya. Dari sosialisasi tersebut peserta didik lebih peduli terhadap kebersihan lingkungan sekitar dengan cara membuang sampah pada tempatnya sesuai dengan jenisnya. Dengan adanya sosialisasi ini peserta didik diajarkan perilaku peduli lingkungan, salah satunya tindakan kerjasama membersihkan sampah-sampah yang berserakan di lingkungan sekolah.

Pada tanggal 22-23 November 2019 yaitu praktik dan pelatihan. Hasil dari pelatihan membuat tempat sampah 
menggunakan bekas tempat cat menjadi tempat sampah. Tim pengabdian mengajarkan peserta didik untuk lebih kreatif mengolah limbah atau barang barang bekas yang masih bisa dimanfaatkan tanpa memungut biaya yang berlebihan. Sebelum diadakan pelatihan, kondisi sekolah tampak kurang teratur, sampah berserakan dimana-mana, bahkan tidak ada tempat sampah untuk membuang bekas jajan siswa. Setelah adanya pelatihan, kondisi sekolah tampak lebih tertata dan siswa mulai sadar akan kewajiban membuang sampah pada tempatnya.

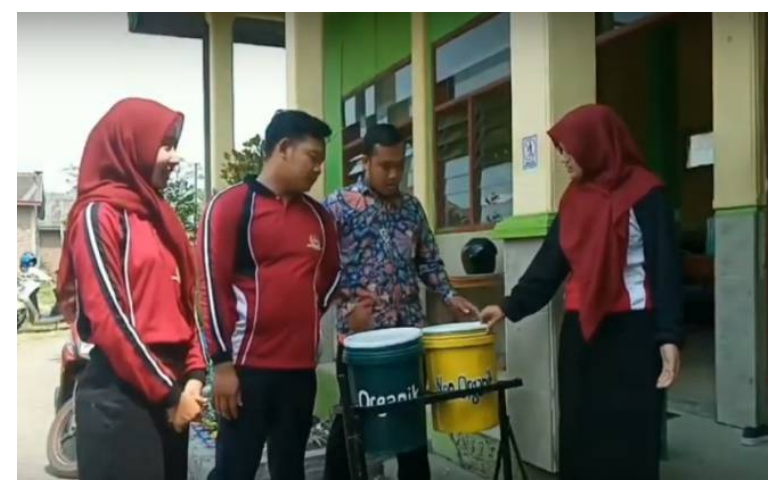

Gambar 3. Pemanfaatan tempat cat bekas menjadi tempat sampah

\section{Kegiatan keempat (25 s.d 27 November 2019)}

Sosialisasi dan pelatihan penanaman tanaman dalam pot bekas dilaksanakan pada hari Senin, tanggal 25 November 2019 pukul 07.00 - 08.00 WIB. Sosialisasi dilaksanakan di lantai atas kelas XII. Sasaran tim pengabdian yaitu semua peserta didik mulai dari kelas X, XI, hingga XII yang berjumlah 45 orang. Tim pengabdian berupaya untuk menanamkan pendidikan karakter peduli lingkungan kepada siswa.

Setelah diadakan sosialisasi maka tim pengabdian melaksanakan pelatihan. Pelatihan dilaksanakan pada tanggal 26 sd 27 November 2019. Tim pengabdian melibatkan seluruh peserta didik yang dibagi menjadi beberapa kelompok. Tim pengabdian memberikan pelatihan pemanfaatan sampah botoh plastik. Tim pengabdian telah menyediakan sejumlah sampah botol plastik, cat, kuas, gunting, cutter, spidol. Pertama, botol-botol plastik dibersihkan. Kedua, membuat pola di botol. Karena tim akan mengubah botol plastik ini menjadi pot yang unik. Setelah pola selesai, lalu digunting sesuai pola. Selanjutnya dicat sesuai dengan yang diinginkan. Kemudian dikeringkan dan terakhir dihias sesuai dengan kreativitas masing-masing.

Pelatihan berlangsung sampai dengan tanggal 27 November 2019. Setelah pot-pot sudah selesai maka tahap selanjutnya penanaman tanaman. Untuk tanaman telah disediakan. Tim pengabdian membeli tanaman hias Spider Plant dan tanaman hias Three Colour, tim pengabdian juga menyediakan pupuk untuk tanaman-tanaman ini. Tim pengabdian bersama siswa menanam tanaman-tanaman hias ini.

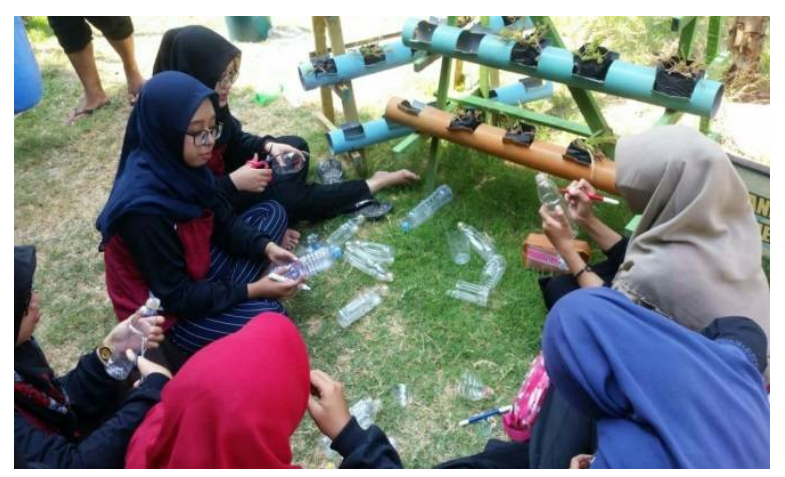

Gambar 4.Pemanfaatan botol bekas sebagai tempat tanaman

Terakhir, tim pengabdian melakukan penataan taman yang ada di depan ruang guru. Tim mengubah taman tersebut menjadi taman yang lebih berwarna dengan adanya tanaman-tanaman hias yang ditanam secara langsung maupun yang terletak di pot-pot hasil karya mahasiswa KKNT dan peserta didik. Untuk menata taman ini, tim memanfaatkan batu-batu di sekitar sekolah, kemudian dicat dan ditata sedemikian rupa di taman. Sisanya tim pengabdian membeli batu hias untuk menambah keindahan taman.

Kegiatan kelima (28-29 November 2019) 
Tahap pertama yang dilakukan dalam pembuatan papan motivasi adalah sosialisasi. Acara sosialisasi ini dilakukan pada tanggal 28 November 2019. Target sosialisasi ini adalah seluruh siswa kelas X, XI, dan XII MA Al Furqon. Sosialisasi ini bertujuan untuk memberi pengetahuan kepada siswa tentang papan motivasi dan memberikan kegiatan apa saja yang akan dilakukan pada proses pembutan papan motivasi. Perlengkapan pembuatan papan motivasi telah disediakan oleh pihak tim pengabdian KKNT, dan para siswa tidak perlu membawa perlengkapan lain. Siswa hanya perlu mempersiapkan kata-kata motivasi yang menarik. Yang nantinya akan ditulis dipapan motivasi.

Tahap kedua adalah pembuatan papan motivasi dan tindak lanjut dari kegiatan sosialisasi. Pembuatan papan motivasi ini dilakukan pada tanggal 29 November 2019, kegiatan ini dimulai pukul 07.00 - 08.00 WIB, dan diikuti oleh seluruh siswa. Papan motivasi ini terbuat dari papan kayu bekas yang sudah tidak terpakai. Kayu bekas ini sudah diberi warna dasar menggunakan cat oleh tim pengabdian KKNT.

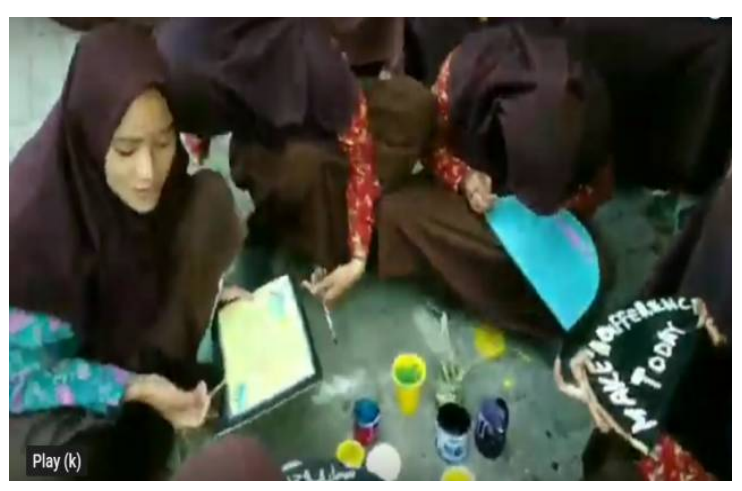

Gambar 5. Membuat Papan Motivasi

Siswa siswi hanya menuliskan katakata motivasi mereka di kayu bekas menggunkan cat warna warni. Setelah siswa siswi menuliskan kata-kata motivasi, papan motivasi kemudian dike-ringkan di bawah sinar matahari. Siswa- siswi terlihat sangat antusias dan banyak kata-kata motivasi yang menarik yang dibuat oleh siswa. Setelah semua papan motivasi kering, tim pengabdian $\mathrm{KKN}$ memberikan pengait diatas papan moti-vasi, yang nantinya dapat digantung dise-luruh lingkungan sekolah.

\section{Kegiatan keenam (30 November 2019)}

Pada pelaksanaa kegiatan labeling ruangan hanya merombak dan memperbaiki tata letak label ruang yang salah serta menambahkan label ruang yang masih belum tersedia. Contohnya seperti laboratorium komputer dan toilet dengan berbahan dasar kayu dan pada tulisannya menggunakan print kertas tebal contohnya seperti pada ruang laboratorium komputer dan ruang UKS. Untuk toilet tim pengabdian menggunakan mika tebal.

Pada tanggal 1-13 Desember 2019 tim pengabdian berkunjung ke MA Al Furqon Bugul Lor seperti biasa, namun kegiatan yang tim pengabdian lakukan sedikit berbeda yaitu mengerjakan laporan selama tim pengabdian melaksanakan kegiatan KKNT di MA Al Furqon Bugul Lor. Pada tanggal 14 Desember 2019 dilaksanakan acara pelepasan mahasiswa KKNT dengan pihak sekolah. Acara pelepasan ini disambut baik oleh kepala sekolah, guru dan staf.

\section{Simpulan}

\section{Penutup}

Tim pengabdian KKNT mengimplementasikan tema kewirausahaan, pendidikan lingkungan, dan budaya literasi di MA Al Furqon Bugul Lor. Kegiatan KKNT berjalan dengan baik, lancar dan menyenangkan bagi siswa. Semua sivitas guru dan siswa-siswi antusias mengikuti kegiatan KKNT dari awal hingga penutupan/evaluasi. Kegiatan tim pengabdian KKNT dilakukan dengan memberikan sosialisasi dan pelatihan pembuatan coklat praline dan karakter, pelatihan pembuatan kerajinan tangan dari kain perca, dan pembuatan tempat sampah organik dan nonorganik serta penanaman tanaman hias pada botol bekas. Dalam bidang budaya literasi siswa-siswi, tim pengabdian melaksanakan kegiatan pembuatan papan 
motivasi, labelling, dan rekondisi perpustakaan sekolah menjadi ruang baca yang lebih representatif.

\section{Saran}

Tim pengabdian KKNT berharap dengan adanya kegiatan ini dapat mengembangkan wawasan dan motivasi siswa-siswi untuk berwirausaha. Selain itu, siswa-siswi MA Al Furqon Bugul Lor dapat memiliki kesadaran untuk menjaga kebersihan lingkungan, serta melakukan reboisasi mandiri dengan memanfaatkan barang/botol bekas. Tim pengabdian KKNT juga optimis bahwa dengan pelaksanaan seluruh kegiatan KKNT ini siswa-siswi MA Al Furqon Bugul Lor dapat meningkatkan semangatberliterasi.

\section{Daftar Pustaka}

Alex, S. (2012). Sukses Mengolah Sampah Organik Menjadi Pupuk Organik. Yogyakarta. Pustaka Baru Press.

Fahmi, I. (2013). Analisis Laporan Keuangan Bandung: Alfabeta. CV.

Hadiyati, E. (2011). Kreativitas dan inovasi berpengaruh terhadap kewirausahaan usaha kecil. Jurnal Manajemen Dan Kewirausahaan (Journal of Management and Entrepreneurship), 13(1), 8-16.

Hisrich, R. D., Peters, M. P., \& Shepherd, D. A. (2008). Kewirausahaan. Terjemahan. Criswan Sungkono Dan Diana Angelica. Edisi, 7.

Kemendikbud, T. P. P. G. L. S. (2016). Panduan Gerakan Literasi Sekolah di Sekolah Menengah Atas. Ditjen Pendidikan Dasar Dan Menengah Kemendikbud.

Muhammad, Y. (2013). Prinsip-prinsip desain pembelajaran. Jakarta: Kencana.

Suharyono, S. (2018). Sikap dan Perilaku Wirausahawan. Ilmu Dan Budaya, 40(56). 